by prominent scientists, were the origins and foundation of all social and legal relations, consolidated the obligation of the state to protect the rights and freedoms, having created the necessary prerequisites for the formation of the society requirements to secure the rights and freedoms, with gradual addition of new principles and institutions to guarantee these rights and freedoms.

Key words: guarantees of human rights and freedoms of citizens, Ukraine, historical and legal research.

УДК 94(477)

DOI https://doi.org/10.32782/2409-4544/2019-2/3

В. Колодяэниа

\title{
Формуваня та розвиток джерел міського права Луцька у складі Волинсько-Галицької держави та Великого князівства Литовського
}

У статті зроблено аналіз формування та розвитку джерел права і інститутів самоврядування Луцька в складі різних держав, досліджена спадкоємність розвитку норм місцевого права на етнічних українських землях, сформованого за часів Київської Русі, Волинсько-Галицької держави і в процесі інкорпорації зарубіжних (німецьких, польських) елементів правового досвіду формування $\mathrm{i}$ функціонування державно-правових інститутів і місцевого самоврядування на Волині в кінці XIIIXVII ст. До основних джерел міського права протягом XIII-XVII ст. відносяться такі первинні нормативні акти: «Руська правда»; грамоти і привілеї про надання місту магдебурзького права 1432, 1497, 1503, 1560, 1576 рр.; статутні грамоти 1501, 1509, 1547 рр.; Жалувана грамота 1457 р.; Судебник 1468 р.; Статут Великого князівства Литовського 1529 р. і його редакції 1566 і 1588 р.p.; збірники магдебурзького права; а похідними від перших - акти органів самоврядування, цехів i судова практика. Особливе місце серед джерел міського права Луцька займає Статут Великого князівства Литовського 1529 р. Цей кодифікований нормативний акт дав новий поштовх до розвитку литовсько-руського права взагалі, і міського права безпосередньо на території усього князівства. Місцеве самоврядування України пройшло складний та досить суперечливий історичний шлях. Започатковані ще у період Київської Русі елементи управління протягом століть постійно зазнавали впливу східної та західної політичних культур, що пояснювалося особливим геополітичним розміщенням держави. Цим пояснюється і особливість формування джерел права середньовічних міст Волинсько-Галицької держави і Великого князівства Литовського, і Луцька, зокрема.

Ключові слова: джерела права, муніципальне право, Магдебурзьке право, ВолинськоГалицьке князівство, Велике князівство Литовське.

Постановка наукової проблеми та їі значення. Для історично-правових досліджень міських громад і міського права останніх років характерне істотне накопичення фактичного матеріалу, аналіз якого утвердив історію громад і муніципального права як окрему сферу наукового пізнання.

У цьому контексті надзвичайно важливим $\epsilon$ дослідження розвитку джерел права середньовічного міста та функціонування на їх основі інститутів місцевого самоврядування, які формували суспільство нового типу в різних регіонах держави i, зокрема, Волині, у складі різних держав у період Середньовіччя та ранньомодерного часу. Це і становить мету і завдання статті.

Виклад основного матеріалу й обгрунтування отриманих результатів дослідження. На початку ХІ століття (1016-1036 рр.) світ побачила Руська Правда, судебник Київської Русі. Вона мала величезне значення для подальшого розвитку українського, російського, білоруського і литовського права [1, с. 56]. У Волинсько-Галицькій державі як правонаступниці Київської Русі в різні часи діяли відомі редакції Руської правди: Коротка, Поширена та Скорочена. Застосування норм Руської правди в Галицько-Волинському князівстві не мало яскраво виражених відмінностей. Руська правда не втратила свого значення з розпадом України-Русі. Ї̈̈ норми знайшли своє відображення у ІІ Статуті Великого князівства Литовського, чинному в Волинсько-Галицькій землі і відомому під назвою Волинського [4, с. 8].

(C) Колодяжна В., 2019 
Міське право Великого князівства Литовського (в історіографії - литовсько-руська доба) до складу якого входила значна кількість тогочасних українських міст, складалося 3 норм, які регулювали відносини між різними верствами міського населення щодо питань міського самоврядування. Слушною $є$ думка В. Кіселичника, що в період середньовіччя поняття "міське право" застосовувалося в трьох значеннях: природне право громадян на самоврядування з власним судочинством, право участі в управлінні торговими та ремісничими об'єднаннями, побудові фортифікаційних споруд; право, як сукупність актів органів міського самоврядування, звичаєве право, яке змінювалось в умовах міста; право на здобуття міського громадянства та правовий зв'язок містянина та міської громади. [6, с.7]

Для формування права Великого князівства Литовського (і міського права зокрема) О. Вовк визначає таку періодизацію:

1. період переваги партикулярних правових звичаїв над нормативно-правовими актами (листами) у матеріальному та процесуальному праві (з моменту приєднання колишніх земель Київського Русі до Литовського князівства - до другої половини XV століття);

2. період становлення литовсько-руського права, коли при збереженні широкого застосування усного звичаєвого права встановлюється його паритет з писаним правом (розпочинається ухваленням Жалуваної грамоти 1457 р., а потім продовжується прийняттям Судебника 1468 р. та Уставних земських грамот);

3. період статутного права, коли загальнодержавне законодавство превалює над звичаєвим правом, що розпочався з моменту видання Статуту Великого князівства Литовського 1529 р. та продовжується введенням у дію його наступних редакцій 1566 р. та 1588 р. [3, с. 4].

Дані про правові звичаї у середньовічному праві, і у міському праві зокрема, підтверджуються творами усної народної творчості, літописними зводами та документальними актами. Так у грамотах міського упорядкування правові звичаї називаються як «обичаї», «старина», «давній обичай» тощо. На їх основі міська громада вирішувала питання соціально-економічного характеру, спільних дій щодо оборони міста, судових спорів, системи оподаткування, збору мита та відробіткових повинностей. Особливе місце міське звичаєве право займало у врегулюванні шлюбно-сімейних відносин. Основні нормативно-правові акти зберігалися в Литовській Метриці - державному архіві Великого князівства Литовського. В містах 3 магдебургським правом Великого князівства Литовського укладачами таких архівів були магістратські або ратушні установи та ремісничі цехи.

Грамоти упорядкування, як правило, надавалися містам великими князями литовськими та королями польськими у двох випадках:

1. за проханням міської громади (міщан, війта, бургомістрів та радців)

2. за скаргою воєводи на міщан [4, с.21].

Від привілейних грамот вони відрізнялися тим, що не змінювали правового статусу міста, а лише вдосконалювали вже існуючий правопорядок, а також, могли надаватися, як містам, де ще існувало старе вічове громадське самоуправління, так і містам на магдебурзькому праві. Грамоти упорядкування могли містити норми, що визначали права і обов'язки міського населення, наприклад, право вільного вибору місця проживання для міщан, забезпечували водні, берегові лісові та інші сервітути членів громади, встановлювали податки, мита та відробіткові повинності, тощо. Надання українським містам магдебурзького права не започаткувало процес створення органів міського самоврядування в Україні, а лише певною мірою модифікувало вже існуючі форми самоуправління.

На думку Рєзнікова О.В., магдебурзьке право це комплекс правових джерел, які в різний час використовувалися в судових органах та органах місцевого самоврядування європейських міст. Серед них на увагу засуговує привілей архієпископа Віхмана м. Магдебургу від 1188 р., що містив норми процесуального та кримінального права. Традиційною була практика використання містами магдебургського права загальнонімецьких джерел права: «Sachsenspiegel» («Саксонське зерцало» 1221-1225pp.) та його пізніших аналогів «Швабське зерцало», «Німецьке зерцало» тощо. Так у XIII ст. деякі положення «Саксонського зерцала» увійшли до правових книг Магдебурга, в тому числі - у «Weichbildvulgata» («Врядувальна книга міської людгості»), яку згодом було перекладено латинською, чеською та польською мовами. Подібні збірники виходили у Німеччині аж до XIX ст $[11$, c. 71$]$.

У Польщі існували латинські переклади, а також і польськомовні видання. Це переробки «Саксонського зерцала» i «Вейхбільда» Конрада 3 Сандомира, Яна Цервуса Тухольчика, Б. Гроїцького, П. Щербича, П. Кушевича. Праці останніх трьох авторів широко використовувалися і в Україні.

Правовою підставою для використання і поширення магдебургського права в українських 
землях були також магдебургські привілейні грамоти, які відігравали таку ж роль, які хартії (статути) західноєвропейських міст та виступали засобом «юридизації» прав міської громади, особистої та майнової свободи міщан та свободи управління містом, тобто власної автономії. [11, с. 73]. Вони були визначальною формою розвитку права тієї доби, аж до прийняття Литовських статутів. Вони поділялися на дві групи. Першу становлять грамоти, де про надання магдебурзькому праву місту вказується уже в самій назві, наприклад «Право майдеборское мещаном чигринским» (1592 р.). Другу - такі, де відсутня вказівка про це у заголовку, але зафіксована у змісті документу.

Також зустрічаємо i, так звані, конфірмації (підтвердження) магдебурзького права, які видавалися на підтвердження одного або декількох привілеїв; підтвердження привілеїв із змінами та доповненнями тощо. Підстави для таких змін могли бути різними: розбійні напади татар, зміна правителів, просторове розширення міст та ін. Часто у привілейних грамотах зазначалося, яке саме місто на магдебурзькому праві береться за взірець. Так, Київ отримав магдебурзьке право на зразок Вільно, Львів - Кракова. [7, с.35].

Яскравим прикладом щодо цього є Луцьк. Перша згадка про це місто датується 1085 р. 3 кінця ХІІ ст. воно розвивалося у складі Волинсько-Галицького князівства.

Луцьк, як центр удільної землі, отримав грамоту на магдебурзьке право у 1432 р. від польського короля Владислава (Ягайла), визнаючи його верховенство. Своїм привілеєм 1432 p. Владислав зрівняв права князів, бояр, воїнів, шляхтичів та інших жителів луцької землі 3 правами, якими користувалися прелати, барони і шляхта Польського королівства, а міщанам Луцька жалував магдебурзьке право. За грамотою лучани отримали низку прав і вольностей. Проте, вочевидь, зрозуміло, що магдебурзьке право розповсюджувалося передусім на заможне населення.

У 1497 р. великий князь литовський Олександр (1461-1506рр.) пожалував Луцьку новий привілей на магдебурзьке право, яке поширювалося вже на усіх міщан. У ньому були значно розширені права луцьких жителів, які органічно доповнювалися їхніми обов'язками перед князівством. В умовах дії магдебурзького права верховний правитель визначив статус і доходи війта, порядок міського управління, вибори чиновників, організацію міського суду. Значна увага приділялася впорядкуванню міського життя, організації у ньому торгівлі. Права і обов'язки лучан було виписано окремою статтею [10, с. 4].

Привілей короля Стефана Баторія 1576 р. підтверджував луцьким міщанам права і вольності, викладені у попередніх привілеях на магдебурзьке право. Цим правом міщани мали користуватися, відступати ж від «їм належного магдебурзького до жодного права в незвичайних речах позиватися не повинні». Це був законодавчий акт, у якому містилася цінна інформація про розвиток міста, основні риси існуючої на той час моделі політико-правового устрою міста, особливості його господарського стану, соціальної структури, повсякденного життя [2, с.16].

У XVI столітті одночасно із систематизацією загальноземського литовсько-руського права відбувається процес упорядкування права окремих міст і земель Великого князівства Литовського. Наслідком цих робіт стало ухвалення низки місцевих нормативних актів, які в історіографії отримали назву Уставних земських грамот (або земські устави) окремим литовським, українським i білоруським землям, повітам та містам.

Iз Уставних земських грамот XVI століття, що були надані окремим українським землям Великого князівства Литовського, зокрема Волинській землі, відомі: «Уставная грамота Литовскаго великого князя Александра, жителямъ Волынской земли», 15 лютого 1501 р., «Уставная королевская грамота жителямъ Волынской области», серпень 1509 р., «Уставна (підтверджувальна) земська грамота Волинській землі» (або «Привілей всій землі Волинській на права і вольності їх») 27 березня 1547 p. [5, c. 20].

Внаслідок кодифікації права на загальнодержавному рівні ухвалення принципово нового зводу законів - Статуту Великого князівства Литовського 1529 року, дія земських уставів повинна була припинитися. Проте Литовський Статут 1529 року та його наступні редакції 1566 та 1588 років, своєю появою не скасовуючи дію Уставних земських грамот все ж таки зупинили систематизаційні роботи міського права. Земські устави за своїм юридичним значенням потрібно прирівняти до місцевих конституційних хартій, а оскільки вони визначали правові взаємовідносини окремих земель 3 центральною владою, то повинні були існувати доти, доки існували ці стосунки.

Привілеї на магдебурзьке право Луцьку XV - XVI століття та Уставні земські грамоти XVI століття красномовно свідчать про стабільність міської політики в Польському королівстві i Великому князівстві Литовському. Вони $є$ збіркою нормативних документів, які містять цінну інформацію про розвиток міста, допомагають реконструювати основні риси наявної тоді в країні моделі політико-правового устрою міських центрів, виявити особливості господарського устрою, 
соціальної структури, повсякденного життя. Ці документи оформили місто Луцьк як самостійну адміністративну одиницю Великого князівства Литовського зі своїми відповідними атрибутами територією, інститутами влади та управління, судом, системою доходів і оподаткування, населенням. Вони визначили засади функціонування магдебурзького права, зокрема, структуру органів влади у місті, основні права і обов'язки посадовців, систему виборів, призначень і їх звітування, діяльність судів та їх компетенцію. Таким чином, верховна влада своїми діями підтримувала розвиток міст, особливо тих, які розташовувалися на кордонах держави. В цьому плані Волинь була стратегічно важливим регіоном як для Корони, так і для Великого князівства Литовського [12, с. 88].

В наслідок систематизації литовсько-руського права у другій половині XV століття великокняжою владою були підготовлені та ухвалені перші загальнодержавні збірники законодавства - Жалувана грамота 1457 р. і Судебник 1468 р., які також можна назвати джерелами міського права. Великий князь литовський та король польський Казимир IV ухвалив на вимогу литовської, білоруської та української шляхти першу загальноземську Жалувану грамоту, яка зрівнювала їх в правах і привілеях 3 польською шляхтою та надавала однакових соціальних прав православній та католицькій знаті та духівництву. Окремі положення цього акту стосувалися і міщан (у грамоті «мєстичов»), яких можна віднести до заможних міських землевласників і прирівняти за правовим становищем до шляхти. Його норми поширювались і на міщан Луцька після надання місту магдебурзького права на самоврядування, якщо його норми не суперечили основним положенням міського права[8, с.11].

Особливе місце серед джерел міського права Луцька займає Статут Великого князівства Литовського 1529 р. Цей кодифікований нормативний акт дав новий поштовх до розвитку литовсько-руського права взагалі, і міського права безпосередньо, на території усього князівства. Створення цього документа було ініційоване при дворі Сигизмунда I на початку XVI століття українською, литовською та білоруською шляхтою та міщанами. Підготовка проекту розпочалася під керівництвом канцлера Миколи Радзивилла Молодшого, а після його смерті в 1522 р. кодифікаційну роботу продовжив канцлер Альберт Гаштольд. 29 вересня 1529 р. цей правовий акт був затверджений розпорядженням великого князя литовського і короля польського Сигізмунда I. Статут Великого князівства Литовського 1529 р. як джерело міського права містить основні принципи формування джерел міського права; конкретні норми міського права; гарантії майнових і особистих немайнових прав міщанського стану. Так, Розділ III, арт. 7 закріплював право на реалізацію наявних свобод і вольностей наданих попередньою та існуючою владою; Розділ I, арт. 1 - право на особисту недоторканість, а саме на те, що ніхто не може бути покараний інакше, як за вмотивованим рішенням суду; Розділ III, арт. 9 - право власності на спадкове майно [9, с.20].

На цьому упорядкування литовського законодавства не припинилося і результатом цієї праці стали Статут Великого князівства Литовського 1566 р., так званий Волинський. Автор не вважав його новим збірником, а лише вдосконаленою редакцією попереднього документу. Проте нова редакція мала більш систематизовану структуру та містила посилання на норми магдебурзького права (Розділ III, арт. 7 «Про міщан права магдебурзького», Розділ III, арт. 30 встановлював в містах 3 магдебурзьким правом еталони виміру об'єму і ваг, тощо) [13, с.101].

Висновки. До основних джерел міського права протягом XIII - XVII століть можна віднести такі первинні нормативно правові акти: «Руська правда», що була складена на основі звичаєвого права і діяла в різні часи у Волинсько-Галицькій державі як правонаступниці Київської Русі; Грамоти (привілеї) про надання місту Луцьку магдебурзького права польського короля Владислава Ягайла 1432 р., великого князя Олександра 1497 та 1503 рр., Жигимонта Августа 1560 р., Стефана Баторія 1576 р.; уставні грамоти; Жалувана грамота 1457 р. і Судебник 1468 р. Великого князя Литовського та короля польського Казимира IV; Статут Великого князівства Литовського 1529 року та його наступні редакції 1566 та 1588 років; збірники магдебурзького права; а похідними від перших - акти самоврядних органів, цехів та судову практику. 3 різних об'єктивних та суб'єктивних причин далеко не всі документи цієї доби дійшли до нашого часу.

Місцеве самоврядування України пройшло складний та досить суперечливий історичний шлях. Започатковані ще у період Київської Русі елементи управління протягом століть постійно зазнавали впливу східної та західної політичних культур, що пояснювалося особливим геополітичним розміщенням держави. Цим пояснюється і особливість формування джерел права середньовічних міст, і Луцька, зокрема. 


\section{Джерела та література}

1. Білецький Л. Руська Правда й історія іiі тексту / Л. Білецький; за ред. Ю. Книша. - Вінніпег: Українська Вільна Академія Наук в Канаді, 1993. - 148 с.

2. Бортнікова А. Привілей Стефана Баторія 1576 р. на підтвердження м. Луцьку магдебурзького права [Текст] / А. Бортнікова // Літопис Волині : Всеукр. наук. часопис / ред. І. Я. Коцан. - Луцьк: Волин. нац. ун-т ім. Лесі Українки, 2011. - Ч. 9. - С. 15-19.

3. Вовк О. Й. Систематизація литовсько-руського права другої половини XV-початку XVI століть: автореф. дис ... канд. юрид. наук / О. Й. Вовк. - Київ : б. в., 2011. - 20 с.

4. Вовк О. Й. Уставні земські грамоти - джерело українського міського права XVI століття / О. Й. Вовк // Вісник Київського національного університету імені Тараса Шевченка. - К.: ВПЦ «Київський університет», 2011. - С. 19-23.

5. Водотика С., Савенок Л. Сучасний погляд на історіографічний доробок історії магдебурзького права в Україні / С. Водотика, Л. Савенок // Scriptorium nostrum. Електронний історичний журнал. 2015. - № 1-2. - С.85-89.

6. Кіселичник В. П.. Міське право Львова (друга половина XIII - початок XX ст.): автореф. дис ... д-ра юрид. наук: 12.00.01 /В. П. Кіселичник. - Київ: б.в., 2012. - 36 с.

7. Кобилецький М. Правовий статус міського населення за магдебурзьким правом / М. Кобилецький // Вісник Львівського університету. - Серія юридична. - 2009. - Вип. 49. - С. 34-40.

8. Колодяжна В. В., Кревський Д. Щодо проблеми міського права м. Луцька / В. В. Колодяжна, Д. Кревський // Актуальні питання реформування правової системи України: збірник публікацій за матеріалами XV Міжнародної науково-практичної конференції. - Луцьк: Вежа-Друк, 2018. - С. 1819.

9. Музиченко П. П. Статути Великого князівства Литовського - видатна пам'ятка права слов'янських народів [Текст] / П. П. Музиченко // Актуальні проблеми держави і права, 2009. - Вип. 49. - С. 7-14. 10. Пам'ятки: археографічний щорічник / Держкомархів, УНДІАСД; редкол.: С. Г. Кулешов (гол. ред.) та ін. - К., 2010. - Т. 11. - 328 с.

11. Резніков А. В. Магдебурзьке право: українські варіації на тему європейських традицій (історикоправовий нарис): монографія / А. В. Резніков / МВС України, Луган. держ. ун-т внутр. справ. Луганськ: РВВ ЛДУВС, 2006. - 208 с.

12. Сеньків Ю. Судебник 1468 року, його структура, зміст та значення / Ю. Сеньків // Вісн. Львів. унту. - Серія юридична. - 2008. - Вип. 46. - С. 59-64.

13. Статут Великого князівства Литовського: у 3 т. - Т. 1 / за ред. С. Ківалова, П. Музиченка, А. Панькова. - Одеса: Юрид. л-ра, 2002. - 297 с.

Колодяжна В. Формирование и развитие источников городского права Луцка в составе Волынско-Галицкого государства и Великого княжества Литовского. В статье сделан анализ формирования и развития источников права и институтов самоуправления Луцка в составе различных государств, исследована преемственность развития норм местного права на этнических украинских землях, сформированного во времена Киевской Руси, Волынско-Галицкого государства и в процессе инкорпорации зарубежных (немецких, польских) элементов правового опыта формирования и функционирования государственно-правовых институтов и местного самоуправления на Волыни в конце XIII-XVII ст. К основным источникам городского права в течение XIII-XVII ст. относятся такие первичные нормативные акты: «Русская правда»; грамоты и привилегии о предоставлении городу магдебургского права 1432, 1497, 1503, 1560, 1576 гг.; уставные грамоты 1501, 1509, 1547 гг.; Жалованная грамота 1457 г.; Судебник 1468 г.; Статут Великого княжества Литовского 1529 г. и его редакции 1566 и 1588 г.г..; сборники магдебургского права; а производными от первых - акты органов самоуправления, цехов и судебная практика. Особое место среди источников городского права Луцка занимает Статут Великого княжества Литовского 1529 г. Этот кодифицированный нормативный акт дал новый толчок к развитию литовско-русского права вообще, и городского права непосредственно на территории всего княжества Литовского. Местное самоуправление Украины прошло сложный и весьма противоречивый исторический путь. Созданные еще во времена Киевской Руси элементы управления на протяжении веков постоянно подвергались воздействию восточной и западной политических культур, что объяснялось особым геополитическим расположением государства. Этим объясняется и особенность формирования источников права средневековых городов Волынско-Галицкого государства и Великого княжества Литовского, и 
Луцка, в частности.

Ключевые слова: источники права, муниципальное право, Магдебургское право, ВолынскоГалицкое княжество, Великое княжество Литовское.

Kolodiazhna V. Formation and Development of the Dources of Lutsk Municipal Law within the Volyn-Halych State and the Grand Duchy of Lithuania. The article analyzes the issue of the formation and development of law sources and self-government institutions in Lutsk, within the periods of different states rule. The study elucidates the continuity in the development of the Ukrainian law norms on the ethnic Ukrainian lands formed during the times of Kievan Rus, Volyn-Halych state and in the process of incorporation of the foreign (German, Polish) elements of legal experience concerning the formation and functioning of the state-legal and self-governing institutes in Volyn at the end of XII century. The main sources of the municipal law formation in the 13th-18th centuries were the following normative acts: «Ruska Pravda», credentials and privileges for granting the city Magdeburg law in 1432, 1497, 1503, 1560, 1576; charter certificates of 1501, 1509, 1547; Certificate of Merit (Brevet) of1457; Sudebnik (Code of Law) of 1468; Charter of the Grand Duchy of Lithuania of 1529 and its revisions of 1566 and 1588; collections of Magdeburg law; and derived from the first - acts of self-government bodies, workshops and court practices. A special place among the sources of city law of Lutsk is occupied by the Statute of the Grand Duchy of Lithuania of 1529. This codified normative act gave a new impetus to the development of LithuanianRussian law in general, and city law directly, throughout the time, when the duchy existed. Local selfgovernment of Ukraine has gone through a difficult and rather contradictory historical way. The elements of government, which was introduced in the period of Kievan Rus have been constantly influenced by Eastern and Western political cultures for centuries, which was explained by the special geopolitical location of the state. This explains the peculiarity in the forming of the sources of law in medieval cities, and Lutsk, in particular. of Lithuania.

Key words: law sources, municipal law, Magdeburg law, Volyn-Galician principality, Grand Duchy

УДК 342.565 .5

DOI https://doi.org/10.32782/2409-4544/2019-2/4

М. Кравчук

\section{Історико-правова характеристика статусу суддів та судового розсуду в період Нового часу}

Ключовим завданням державних органів в сучасній правовій державі $є$ захист прав, свобод і законних інтересів людини і громадянина, тому за допомогою національного законодавства держава намагається створити відповідну судову систему, яка б сприяла реалізації поставленого завдання. Разом 3 тим, судова система будь-якої держави формується не тільки на основі сучасного законодавчого врегулювання, а й 3 використанням історичних напрацювань, які формувалися століттями. Дане дослідження обумовлюється необхідністю історико-правової характеристики проблеми суддівського розсуду і підготовки на цій основі рекомендацій, які можуть мати значення для подальшого вдосконалення правозастосовчої діяльності. Для досягнення зазначеної мети в процесі дослідження були проаналізовані фактори, які впливали на судовий розсуд і особливості винесення судового рішення в період Нового часу в країнах Європи. Зроблено висновок про те, що істотний вплив на суддівський розсуд у період Нового часу, Просвітництва, Відродження справив розвиток природно-правової та позитивістської концепцій праворозуміння. Період XVIII-XIX століть характеризувався посиленням ролі позитивізму на фоні бурхливого розвитку капіталістичних відносин, масових відкриттів у науці та техніці, що сприяли раціональному поясненню природного права. При цьому пріоритетними були етичні постулати, моральні закони та імперативи, які доповнювали позитивне право, що спростовувало його неспроможність регулювати суспільні відносини. Проголошення юридичного позитивізму основоположною течією XIX століття призвело

(С) Кравчук М., 2019 